\title{
A REVIEW OF THE DISTRIBUTION AND HABITATS OF NORTH AMERICAN BRATHINUS (COLEOPTERA; STAPHYLINIDAE; OMALIINAE)*
}

\author{
By Stewart B. Peck \\ Department of Biology, Carleton University, \\ Ottawa, Ontario $\mathrm{K}_{\mathrm{IS}}{ }_{5} \mathrm{~B} 6$, Canada
}

The genus Brathinus, with one Japanese species and three in the United States and Canada, has been considered either as the basis for the monogeneric family Brathinidae (such as in Arnett, I963), or as belonging to the Staphylinid subfamily Omaliinae (such as in Hatch, 1957, and Crowson, 1967). Hammond (1971) has reviewed the question, has presented a series of eleven morphological characteristics of the Omaliinae possessed by Brathinus, and has concluded that Brathinus belongs in this subfamily. In addition, he provides a key to the species, illustrations of the male genitalia of the American species, and comments on the rarity of distribution and habitat data. The purpose of this paper is to provide additional habitat data and to contribute to an understanding of the distribution of the North American species.

The data are drawn mostly from my own records and collecting, and from material in the collections of the California Academy of Sciences, San Francisco (CAS), the Canadian National Collection of Insects, Ottawa (CNC), the Field Museum of Natural History, Chicago $(\mathrm{FMNH})$, the Illinois Natural History Survey, Urbana (INHS), the Museum of Comparative Zoology, Harvard University (MCZ), and the United States National Museum, Washington, D. C. (USNM). In the following records, the locality and habitat data are given first, then, when available, the month of collection in lower case Roman numerals, the number of specimens, and the abbreviation of the collections containing the material.

\section{Brathinus nitidus Leconte 1852}

The species ranges (map I) from Newfoundland and Nova Scotia westwards to the Lake Superior Region, and south along the Appalachians to northern Alabama. It is associated with cool riparian and bog habitats, usually in shaded situations, in moss or wet plant roots or under stones, and especially in the spray zone of waterfalls. C. Lindroth (in Hammond, I97I) observed the beetles emerging

*Manuscript received by the editor March 17, 1975 
from earthworm-like holes in damp soil on the banks of a Newfoundland river. Most of the more southerly records of the species are from caves, where the beetles are probably seeking the cooler, more moist, and darker conditions. In caves, the beetles seem to be able to survive quite well in the dark zone as well as in the twilight zone, but the association with caves is only a facultative (troglophilic) one, in spite of the cavernicolous characteristics of the beetles' thin cuticle and reduced pigmentation.

Barr (1968: 8I) indicated that there was a cave-specialized (troglobitic) brathinid in lava tube caves in southeastern Idaho, but this is the leiodid (sensu latu) Glacicavicola bathyscioides Westcott (1968) which has converged to look remarkably like Brathinus (Peck, 1970, 1973, 1974). The omaliine characters cited by Hammond aid in separating Glacicavicola from this subfamily of staphylinids.

Adults have been collected in February and from May through November, but are most often taken in the summer months. At least in the southern Appalachians and in caves the beetles may pass the winter as adults.

I have seen the following material:

Canada. Newfoundland. Mountains east of Codroy, vii, I, MCZ. Steady Brook, vii, 2, CNC.

Quebec. Comté Brome. Knowlton, vi, I, CNC. Comté GaspéEst. Gaspé, vi, 23, CNC. Comté Gaspé-Ouest. Mont Albert, viii, I, CNC. Comté Montmorency. Lac J. Cartier, Parc des Laurentides, vi, I; viii, 2, CNC. Mare-du-Sault, Parc des Laurentides, viii, 3, CNC. County unknown. Pt.-aux-Saumons, vii, I, CNC. SteMathilde, vi, I, CNC.

United States. Alabama. Dekalb County. Fort Payne, Manitou Cave, I (Univ. Alabama Museum Natural History). Limestone County. Spence Cave, along cave stream in gravel, viii, 4, SBP. Madison County. New Hope, Cave Spring Cave, x, 3, INHS. Marshall County. Kirkland Cave, along stream, ix, I, SBP. Natural Bridge Cave, along stream, xi, I, SBP. Morgan County, $3.5 \mathrm{mi} \mathrm{SE}$ Fayette, forest litter at cave entrance, v, I, SBP.

Kentucky. Carter County. Carter Caves State Park, Bat Cave, along stream, vii, I, SBP. Elliott County. Tar Kiln Cave, along stream, v, I ; viii, 3, SBP. Jackson County. Station Camp Creek, in wet gravels, v, I, SBP. Powell County. Betsy Cave, vii, I, FMNH.

Maine. Grafton, v, I, MCZ. 
Michigan. Keweenaw County. Eagle Harbor, vi, 7, USNM. Marquette County. Huron Mountains, viii, I8, USNM. Marquette, vii, 2, USNM.

New Hampshire. Ammonoosuc River shores, vii, 3, MCZ. Fabyans, Ammonoosuc River, 2, MCZ. Franconia, 12, MCZ. Mount Madison, I, FMNH. Mount Pleasant, ix, I, MCZ. Mount Washington, 3500-5000 feet, vii, 3 ; viii, II; ix, 3 ; no date, I; CNC, MCZ. Rumney, vi, I, MCZ. White Mountains, in woods, 3, MCZ; no other data, 3, CNC, USNM.

New Jersey. Fort Lee, I 4, MCZ, USNM. State label only, 3, USNM.

New York. Jefferson County. Watertown, Ice Labyrinth Cave, on damp silt floor, $\mathrm{x}, 4$, SBP. Ulster County. Olivera, vi, 6, USNM, CAS. Westchester County. Peekskill, v, 32, CAS, CNC, FMNH, MCZ, USNM; xii, I, MCZ. County unknown. Pike, vii, I I, CAS, FMNH, MCZ; Slide Mountain, Catskills, vi, 6, USNM. State label only. 3, CAS, MCZ.

Tennessee. Cumberland County. Mill Cave, flood debris at base of dome at far wall of upper entrance, vii, I, SBP. Grundy County. Monteagle, Wonder Cave, vi, I, USNM; ii, I, CAS. Hamilton County. Lookout Mountain, v, 2, USNM, INHS. State Label only, 7, INHS.

Virginia. Scott County. Flannery Cave, Rye Cove, along stream, $\mathrm{xi}, \mathrm{I}, \mathrm{SBP}$.

Vermont. Stowe, vi, 2, USNM.

West Virginia. Tucker County. Blackwater Falls State Park, wet moss mats at falls base, vi, I, SBP.

The species is also reported from an unspecified locality in Nova Scotia by Hammond (I97I) and from Frenchman's Cave, St. Croix, Hants County, Nova Scotia (Calder and Bleakney, 1967).

Dr. T. C. Barr, Jr. (in litt.) reports the species from the following additional localities: Kentucky. Jessamine County. Spring on upper Clear Creek. Tennessee. Overton County. Mill Cave; and a sinkhole near Obe Lee Cave. Putnam County. Terry Cave.

Dr. M. W. Sanderson (in litt.) reports taking the species in northern Illinois, but the specimens cannot be located.

Larvae of Brathinus are not reported, but a larva associated with the Mill Cave (Cumberland County, Tennessee) population was taken by Barr, and examined by M. W. Sanderson who found it to have omaliine characteristics. I have tried to obtain more larvae from this and other cave populations but have been unsuccessful. 

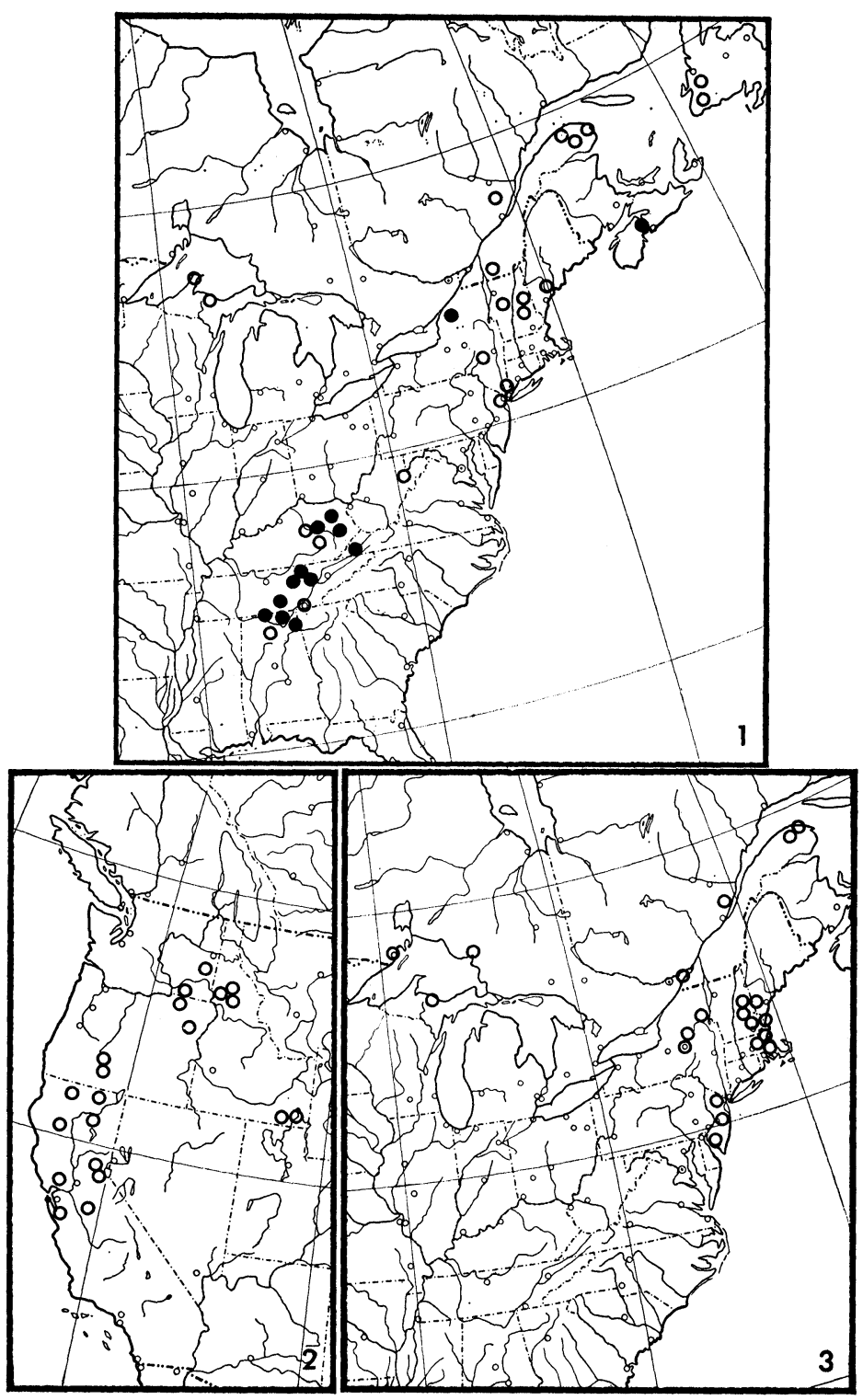

Maps 1-3. Map 1. Distribution of Brathinus nitidus. Open circles are above-ground localities. Dark circles are cave localities. Map 2. Distribution of Brathinus californicus. Map 3. Distribution of Brathinus varicornis. 
Brathinus varicornis Leconte 1852

The species ranges (map 3) from Quebec and Ontario southward to Michigan and through the northeastern states to New Jersey. The habitat notes are fewer for this species but they suggest cool riparian or swampy-boggy situations.

Adults have been collected from May through October.

I have seen the following material:

Canada. Ontario. Michipicoten River, viii, 5, MCZ, USNM. Thunder Bay, I, CNC.

Quebec. Comté Charlevoix-Est. St. Fidèle, vi, I, CNC. Comté Gaspé-Ouest. $6 \mathrm{mi}$ S Riviere-a-Claude, Iooo feet, vii, I, CNC. Parc Gaspesie, Lac Cascapedia, I70o feet, vii, 2, CNC. Comté Vaudreuil. Rigaud, vi, I, CNC.

United States. Maine. Bethel, vi, viii, x, I I, MCZ. Kittery Point, II, MCZ.

Massachusetts. Brookline, ix, I, MCZ. Framingham, treading and sifting wet leaves in wooded swamp, vi, 6; v, 6, CAS, CNC, FMNH, MCZ, USNM. Lexington, vi, I, MCZ. Natick, dead grass in swamp, x, I, MCZ. Newton, x, I, MCZ. Wakefield, I, MCZ. Wayland, grass in water, vi, $\mathrm{I}, \mathrm{MCZ}$.

Michigan. Marquette, vii, 4, MCZ, USNM. "L.S.", perhaps meaning Lake Superior, I, MCZ.

New Hampshire. Exeter, swamp treading, 2, MCZ. Farmington, viii, 5, MCZ. Rumney, vi, 2, MCZ. Mt. Washington, ix, I, $M C Z$.

New Jersey. Bridgeton, v, 3, USMN, FMNH. Hilldale, ix, I, MCZ. Monmouth Junction, x, 4, USNM. No other data, v, 4, CAS.

New York. Essex County. Newcomb, Huntington Forest, from Sphagnum in swamp, vii, I, W. R. Suter collection. Herkimer County. Thendara, from Sphagnum in swamp, vi, 5, W. R. Suter collection.

Leonard ( I926) cites the species from Utica, New York.

Hatch (1957: 53) cites all material from the Pacific Northwest under this name but they are undoubtedly referable to the following species.

\section{Brathinus californicus Hubbard I 894}

The species ranges (map 2) from the San Francisco area of California northward along the coastal and interior mountains through Oregon to Washington and Idaho. The species is associated with damp moss, and cool, mountain-streamside situations. 
Adults have been collected from April through August.

I have seen the following material:

United States. California. El Dorado County. Emigrant Gap, v, I, CAS. Lake Tahoe, vii, 28, FMNH, USMN. Tahoe City, 2, CAS. Modoc County. Cedar Creek, E slope Cedar Pass, 5300 feet, viii, 3, CAS. Napa County. No other data, I2, CAS. Santa Clara County. San Jose, iv, I, CAS. Shasta County. Burney Falls, vi, 2, CAS. Siskiyou County. Shasta Retreat, 24I6 feet, vii, I, CAS. Sisson, vii, 8, CAS, CNC, MCZ, USNM. No other locality data, vii, 2o, CAS, FMNH, MCZ, USNM. Stanislaus County. Adobe Creek, $22 \mathrm{mi} \mathrm{W}$ Patterson, iv, 3, CAS. Trinity County. Butler Creek, 12 mi SE Hyampom, 3450 feet, in aggregation with Stenus under loose bark of Abies log by creek, vii, I30, CAS.

Idaho. Latah County. Moscow, Cedar Mt., v, 2, MCZ. County unknown. Willow Flat, Cub River Canyon, Wasatch Mts., I, FMNH.

Oregon. Baker County. Pine Creek, near Baker, on debris partly in swift stream, vi, I6, FMNH. Klamath County. 6 mi S Ft. Klamath, Crooked Creek, treading creek-side grass, vi, 9, CNC. $9 \mathrm{mi}$ NE Bly, Deming Creek, 5000-580o feet, treading moss under Alders, vi, 8, CNC. Umatilla County. Meacham, v, I3, USNM.

Washington. Whitman County. Palouse, $\mathrm{x}, 2$, MCX. Walla Walla County (?). Kooskoosie, vi, I, USNM.

Hatch (1957: 53) adds the following localities from which I have not seen material: Idaho; Deary, Elk River, and Franklin County. As noted above, these and other localities of Hatch were listed under the name $B$. varicornis, not californicus. In discussing this species, Hammond ( 1971 : 68) gives east Wisconsin as part of the range, but this is a misinterpretation of the symbol "e Wn." used by Hatch to signify eastern Washington.

\section{Zoogeographic Considerations.}

The distribution of the genus is disjunct, occurring in Japan and temperate North America. This is not an uncommon distribution disjunction. It is shown in many plant genera $(\mathrm{Li}, 1952)$, is generalized as an Asian-American distribution type by Thorne (1972), and, except for the presence of $B$. californicus, is an example of the east Asian-eastern North American disjunct pattern of Darlington (1957:4I7), based on vertebrates. From my observations, and data provided by Hammond on $B$. oculatus Lewis of Japan, I suggest the following distributional-evolutionary history. 
The genus had a continuous distribution from Asia through Beringia into and across North America in the Tertiary. The ancestral species nitidus-californicus may have been limited to North America, but ancestral varicornis-oculatus ranged from Asia across Beringia to eastern North America. With the progressive deterioration of climates in the Pliocene, the Beringian distributional link of this second ancestral species was broken, and the Asian population evolved into oculatus, and the North American populations into varicornis. The western North American populations of varicornis were eliminated by fluctuating Pleistocene climates, and the species became restricted to eastern North America. The range of ancestral nitidus-californicus was formerly across North America, but it became broken into two, in the mountains of eastern and western North America, during the fluctuating climatic events of the Pleistocene. Population separation and subsequent speciation into nitidus and californicus was facilitated by a dry-warm central continental climate in the Sangamon Interglacial or during an earlier interglacial. Later dispersal and expansion of ranges southwards was during the Wisconsin glacial. This is especially true for the expansion of nitidus south along the Appalachians. Both nitidus and varicornis have expanded northwards into formerly glaciated lands since deglaciation. Their southern limits may be contracting as warmer and drier interglacial conditions return. B. nitidus, because of its preadaptation for cool and moist conditions, is now favoring caves in the southeast because they can serve as climatic refugia (Barr, 1968: 80).

\section{Acknowledgements}

I wish to thank J. F. Lawrence ( $\mathrm{MCZ}$ ), J. Milton Campbell and Ales Smetana (CNC), Henry Dybas (FMNH), Milton W. Sanderson (INHS), J. M. Kingsolver (USNM), and Hugh B. Leech and David H. Kavanaugh (CAS) for permitting the examination of material in the collections under their care. Walter R. Suter, Thomas C. Barr, Jr., J. Milton Campbell, Ales Smetana, and M. W. Sanderson gave or corresponded on material or on their field experiences with Brathinus. Most of my personal data on Brathinus were gathered during field work supported by NSF grants GB 3167 and GB 7346 to the Evolutionary Biology Committee, Harvard University, Professor Reed C. Rollins, principal investigator, and by Canadian National Research Council operating grants. The manuscript was read by J. M. Campbell, M. W. Sanderson, and J. F. Lawrence. 


\section{Literature Cited}

ARNETT, R. H.

1961. The beetles of the United States. (A manual for identification.) Catholic University of America Press, Wash., D. C. 1112 pp.

BARR, T. C.

1968. Cave ecology and the evolution of troglobites. in: Evolutionary Biology, T. Dobzhansky, M. Hecht, W. Steere eds., 2: 35-102. Appleton-Century-Crofts, New York.

Calder, D. R. and J. S. Bleakney.

1967. Observations on Frenchman's Cave, Nova Scotia and its fauna. Bull. Natl. Speleol. Soc. 29: 23-25.

Crowson, R. A.

1967. The natural classification of the families of Coleoptera. Reprint. E. W. Classey Ltd., Middlesex, England. $214 \mathrm{pp}$.

Darlington, P. J.

1957. Zoogeography: the geographical distribution of animals. John Wiley \& Sons, New York, 675 pp.

HAMMOND, P. M.

1971. The systematic position of Brathinus Leconte and Camioleum

HaTch, M. H. Lewis (Coleoptera; Staphylinidae). Jour. Ent. (B) 40: 63-70.

1957. The beetles of the pacific northwest. Part II: Staphyliniformia. Seattle: Univ. Wash. Pub. Biol. 16, 384 pp.

HubBard, H. G.

1894. Notes on Brathinus. Proc. Ent. Soc. Wash. 3: 10-12.

LEConte, J. L.

1852. Synopsis of the Scydmaenidae of the United States. Proc. Acad. Nat. Sci. Philadelphia 6: 149-157.

LEONARD, M. D.

1926. A list of the insects of New York, with a list of the spiders and other allied groups. Cornell Univ. Agric. Exp. Sta. Mem. 101, $1121 \mathrm{pp}$.

Li, HUi-Lin.

1952. Floristic relationships between eastern Asia and eastern North America. Trans. Amer. Phil. Soc. 42 (2) : 371-409.

Peck, S

1970. Notes on the biology of the eyeless beetle Glacicavicola (ColeopPeck, S. B. tera: Leiodidae). Annales Spéléol., 25: 235-237.

1973. A review of the invertebrate fauna of volcanic caves in western North America. Bull. Natl. Speleol. Soc. 35 (4) : 99-107.

1974 Biology of the Idaho lava tube beetle, Glacicavicola. Bull. Natl. Speleol. Soc., $36: 1-3$.

THORNe, R. F.

1972. Major disjunctions in the geographic ranges of seed plants. WESTCOTT, $R$. Quart. Rev. Biol. 47 (4) : 365-411.

1968. A new subfamily of blind beetle from Idaho ice caves with notes on its bionomics and evolution (Coleoptera: Leiodidae). Contr. Sci., Los Angeles County Mus. Nat. Hist., no. 141: 1-14. 

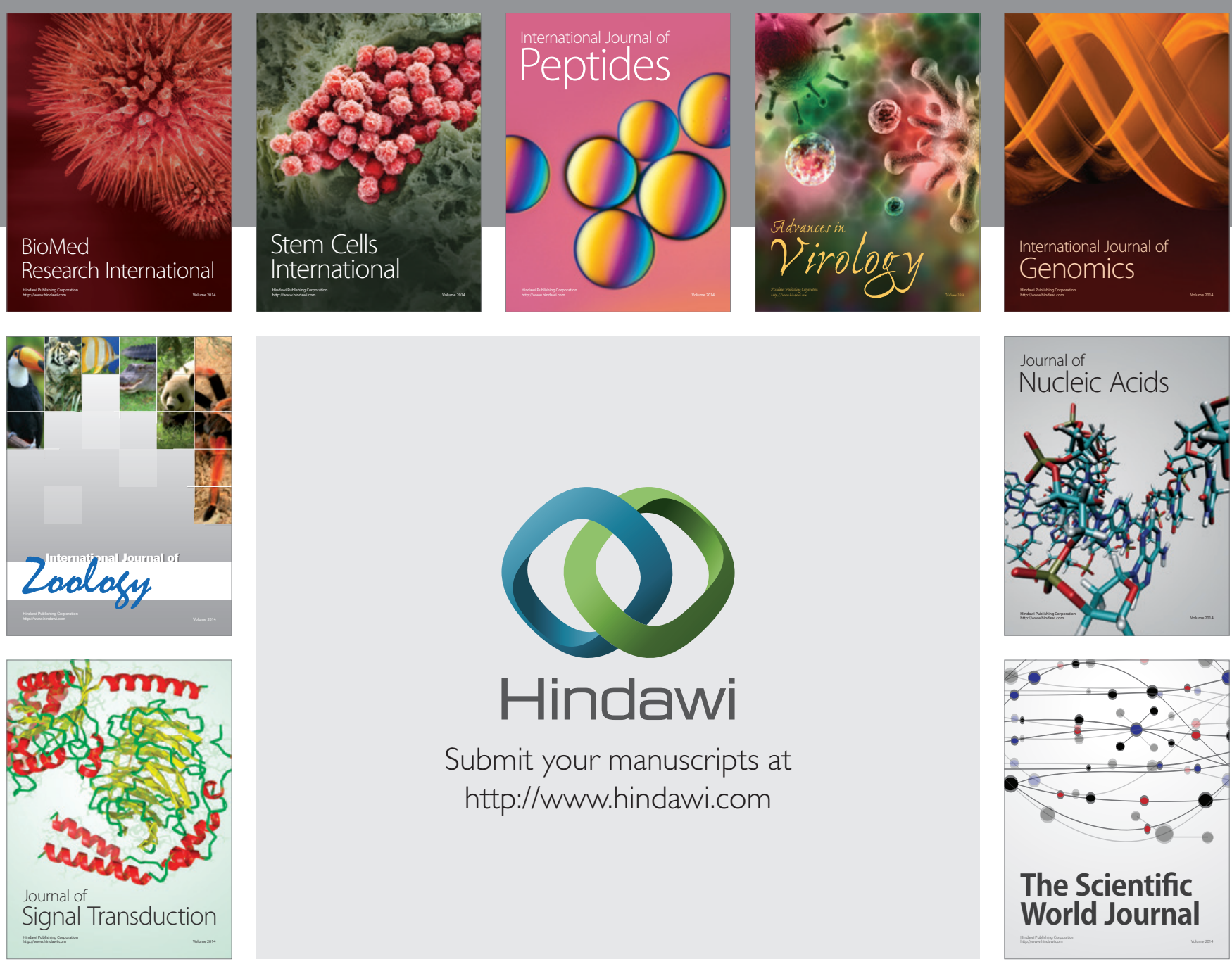

Submit your manuscripts at

http://www.hindawi.com
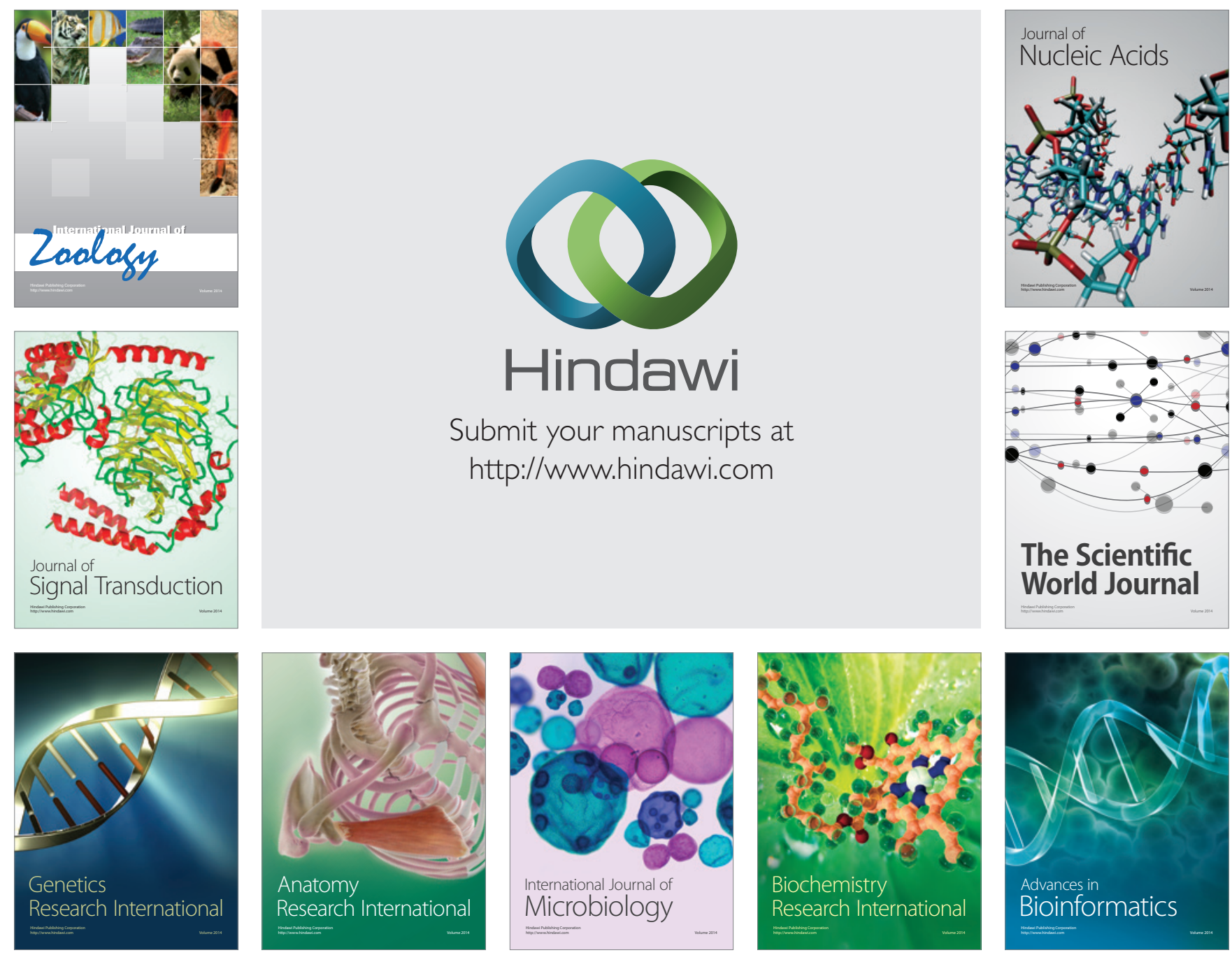

The Scientific World Journal
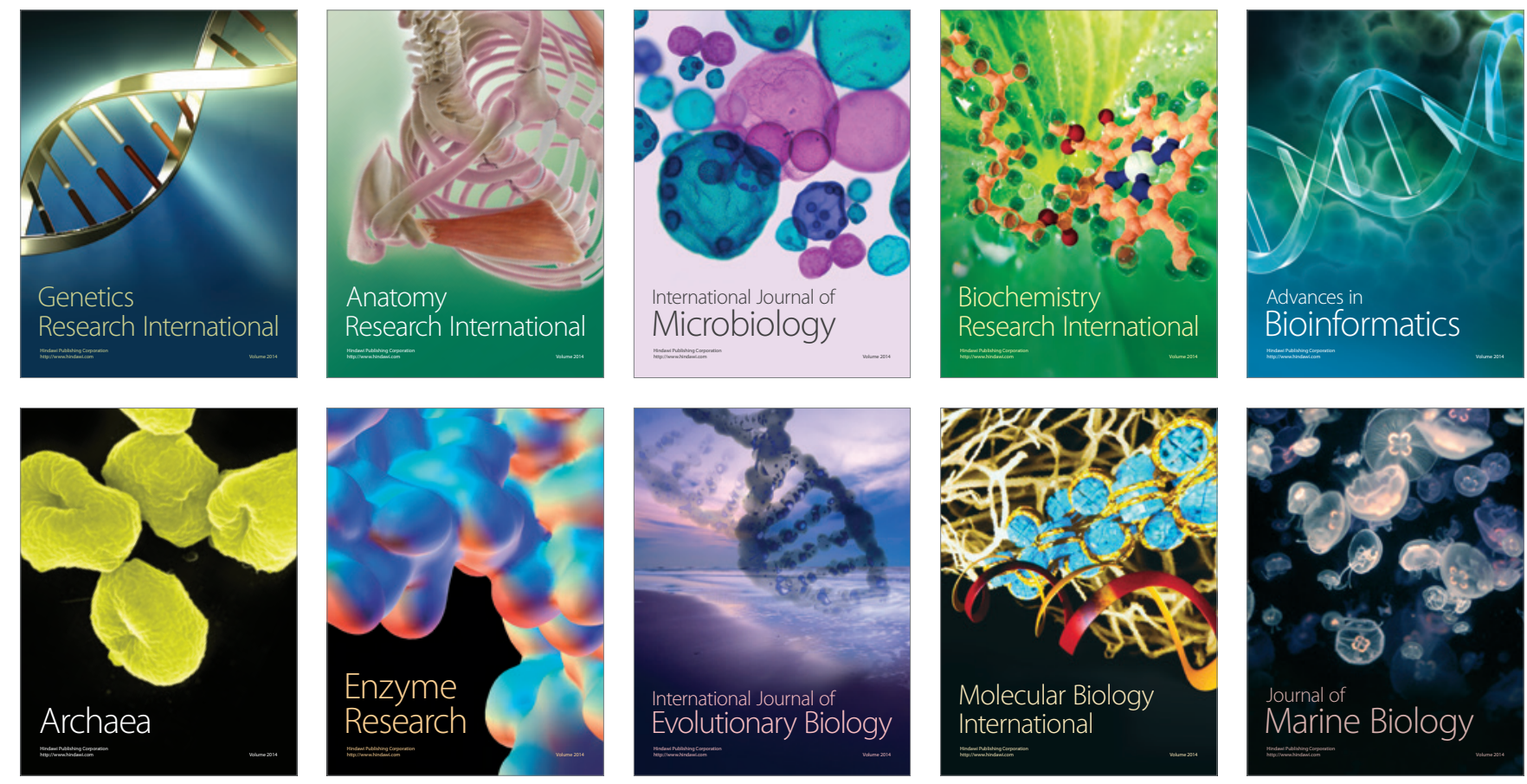